\title{
Alexander von Humboldt's letters to Sergey Uvarov in the Russian manuscript collections
}

\author{
E.G. Pivovarov \\ Doctor of history, Leading researcher, St. Petersburg Branch of the Institute for the History of Natural \\ Sciences and Technology, Russian Academy of Sciences, St. Petersburg, Russia
}

\author{
A.Yu. Skrydlov \\ PhD in history, St. Petersburg Branch of the Institute for the History of Natural Sciences and Technology, \\ Russian Academy of Sciences, St. Petersburg, Russia
}

\begin{abstract}
The year of 2019 was significant for A. von Humboldt studies in Russia. The prominent Prussian researcher was familiar with a lot of scientists and statesmen in our country. The press hugely covered his famous voyage to the Empire in 1829. Humboldt's public lectures in the Academy of Sciences and other Imperial institutions were held with resounding success. The same year he got acquainted with S.S. Uvarov, the Academy President. Their correspondence, lasting for many years, has not been comprehensively studied yet. The authors revealed previously unpublished documents allowing to investigate their relationships. Humboldt often reminded about his German colleagues, having obtained positions in Russia. Due to his patronage, the future Academy of Sciences members (G.V. Abih, L.M. Kämtz, A. Y. Kupfer, Yu.F. Fritz) were invited to the country. He repeatedly complained about such "brain drain" caused by the fact that those specialists could build their scientific careers more successfully in Russia than in Germany. Humboldt and Uvarov constantly sent their books and articles, discussed international book exchanges, tried to create the journal, devoted to the Asian studies. Their correspondence continued after Uvarov's dismissal from the Ministry of National Education. In their last letters they frequently lamented about the revolutionary extremes of the epoch.
\end{abstract}

\section{INTRODUCTION}

Alexander von Humboldt's ideas hugely influenced the development of natural studies in Russia. In 2006 Natalia Suhova compiled the bibliography describing over 350 articles and books, devoted to his legacy, having been issued in our country (Suhova, 2006). Dozens of new works have been written since then. A new wave of the public interest was inspired by the joint jubilee: Humboldt's personal and the anniversary of his "Russian" voyage. Several Russian archives are holding over 200 letters written from/to the Prussian polymath. For decades he corresponded with a wide range of Russian scientists and authorities. Some of those documents were published in the USSR in 1962 (Shcherbakov, 1962).

Our article is an attempt to continue our Institute predecessors' investigations. We are trying to trace some aspects of long lasting relationships between Humboldt and Sergey Semionovich Uvarov, an influential statesman during Nicholas I reign, the Minister of National Education and the Imperial Academy of Sciences (IAS) President. During the Soviet period the latter was regarded as one of the most high-ranking standpatters of that time. His famous triad "Orthodoxy, Autocracy, and Nationality" was heavily criticized by the Marxist scholars. The compilers of the 1962 edition tried to avoid promulgating a great deal of his "ideologically dangerous" correspondence. It is not easy to imagine some of their doxology towards monarchs to be issued that time by the USSR Academy of Sciences. 
On 27 March, 1833, Uvarov, having been recently appointed a minister exclaimed: "No one is better aware than I myself, how weak is my strength to bear the burden, entrusted to me by His Majesty, but I dare say, that no one would have reacted to this important and difficult matter, with such selfless devotion to the country and the monarch whose high and rare advantages, you, yourself, had the opportunity to evaluate. His intentions regarding public education are as wise, as fatherly, as enlightened as in other areas of government" (Rossijskij Gosudarstvennyj Istoricheskij Arhiv (henceforth RGIA), coll. 735, aids 1, fol. 413, pp. 7, 16).

\section{SOURCES REVIEW}

Obviously, it is impossible to reconstruct all circumstances of their multiple collaborations without revealing letters, having survived in the European archives and any involvement of other types of sources. We have tried to make a general overview of Humboldt's appeals to Uvarov, kept in our country. Nowadays, 17 identified letters are held in Russian archives. 9 were previously published in the original language (Otdel Pis'mennyh Istochnikov Gosudarstvennogo Istoricheskogo Muzeja, Moscow (henceforth OPI GIM), coll. 17, aids 41/174, p. 201 in Knobloch, 2009) or in Russian translation (Sankt-Peterburgskij Filial Arhiva Rossijskoj Akademii Nauk (henceforth SPbF ARAN), coll. 1, aids 3, fol. 81, p. 208; RGIA, coll. 735, aids 1, fol. 413, p. 8; OPI GIM, coll. 17, fol. 41/174, p. 192; Otdel Rukopisej Rossijskoj Nacional'noj Biblioteki, St. Petersburg (henceforth OR RNB). Coll. 991, fol. 603, pp. 1-4; OPI GIM, coll. 17, fol. 41/174, p. 193; p. 194; p. 195-196; p. 197). 8 items are a still waiting to be properly investigated (OPI GIM, coll. 17, fol. 41/174, p. 204; RGIA, coll. 735, aids 1, fol. 413, p. 9; p. 10; p. 11; p. 13-14; OPI GIM, coll. 17, fol. 41/174, p. 198; p. 199-200; p. 227-228 in Shcherbakov, 1962.).

Besides, Russian manuscript repositories hold a number of Humboldt's letters to "unidentified persons". Judging by their content, in several cases, Uvarov might have been a hypothetical recipient. Such documents final attribution is a complicated task. Lack of any substantial evidence prevents us from quoting them. Only two such documents will be mentioned. The files cover of the first (OR RNB. Coll. 965, fol. 1310, p. 1) suggests, that the letter might belong to "Prince Lobanov". Probably, - a famous collector A.Ja. LobanovRostovsky. Such opinion is based on a handwritten pencil inscription, made within the text. However, we suppose that neither he nor any of his relatives were able to resolve Humboldt's questions. While Uvarov was the person, being authorized to do it. We have ventured to cite that bright example of the scientist's care about his younger colleagues. The second one (RGIA, coll. 735, aids 1, fol. 413, p. 6) is held in the National Education Minister Office collection alongside with other letters from the Prussian naturalist to Uvarov. Its plot, content, and design evidence quite clear whom they were sent to.

\section{ACQUAINTANCESHIP}

They knew each other, although probably fist in absentia since the 1810-s. Notifying on 18 April 1835 about the death of his brother Wilhelm, an IAS honorary member, Humboldt wrote: "My brother, during his stay in Vienna [Uvarov was in Vienna at the Russian Embassy in 1806-1809. W. Humboldt was a Prussian Ambassador to Vienna in 1810], had the pleasure of being on friendly terms with Your Excellency [Uvarov], and saw at the early successes of yours in the noble field of classical literature" (SPbF ARAN, coll. 1, aids 3, fol. 81, p. 208).

In 1818, the scientist was also elected as an honorary member (SPbF ARAN, coll. 1, aids 1a, 1818, fol. 29, § 71). On 11 February 1818, several IAS members - "academicians" signed Uvarov's preposition to elect "baron Alexander von Humboldt, well-known for his scholarship and merits" (SPbF ARAN, coll. 1, aids 2, 1818, fol. 71). On 7 October 1818, the General Assembly noted that he had thanked for the "honor" to become its affiliate. He was especially grateful for Uvarov, "speaking with the high esteem about the accomplishments of the present President, exploring with such incomparable wisdom the most mysterious sources of antiquity 
and combining with extensive knowledge that noble independence of the opinion, by which the Enlightenment should inspire everyone in any life vicissitudes" (SPbF ARAN, coll. 1, aids 1a, 1818 , fol. $29, \S 356$ ).

Humboldt and Uvarov finally met in person in 1829 (OPI GIM, coll. 17, aids 41/174, p. 204), when the German explorer was invited by the Russian Minister of Finance Georg von Cancrin to visit the Empire. He recalled on 30 July 1852: "I am a little proud of possessing a "heart memory" and therefore do not forget the deep impression, that your reading made on me 23 years ago: you honored me then with special trust <...>" (OPI GIM, coll. 17, fol. 41/174, pp. 199-200). His voyage aroused enthusiasm among Russian aristocrats. Humboldt wrote to his brother: "My beau monde successes are beyond description. All the nobles, all the scientists - all of them constantly revolve around me. No one might be accepted with a greater respect and hospitality $<\ldots .>$. Almost every day I have lunch with the Imperial family in a narrow circle - the table is set for four people" (Suhova, 2006).

There were numerous notes in the Russian periodicals dedicated to the scientist. Thus, a famous litterateur Pavel P. Svinyin informed his "Otechestvennye Zapiski" readers: "He was honored to be invited to the Sovereign Emperor's dinner table and then daily received invitations to our grandees, trying to show him all their respect and Russian hospitality" (S[vin'in], 1829).On 29 April 1829, Humboldt made a report at IAS and soon after that undertook a seven months expedition to the Asian part of the Empire. There, he got acquainted with the local science lovers. Four years later he wrote to Uvarov, that he regularly and warmly recalled about "the geographical data treasury" in Orenburg, collected by a military engineer Gregory F. Gens (RGIA, coll. 735, aids 1, fol. 413, pp. 8).

Upon his coming back to St. Petersburg, Humboldt again visited IAS. The "Extraordinary Meeting" on 16 November 1829 was attended by "Her Majesty Grand Duchess Elena, <. . > Duke Alexander of Württemberg, noble persons from the Imperial Court, State Council members, corps diplomatique, the Minister of Public Education <...>, ministers, the Academy honorary and correspondent members and a large number of dignitaries of both sexes, scientists and writers of our capital" (SPbF ARAN, coll. 1, aids 1a, 1829, fol. 41). Speeches, made by the guest, Uvarov, and academicians were published (Séance extraordinaire. .., 1829).

\section{PATRON OF YOUNG SCIENTISTS}

Soon their personal acquaintance grew into continuous and steady correspondence. Its key issue was scientists' employment. Humboldt frequently recommended German geographers, mineralogists, philologists to vacant positions in Russian universities. Several future academicians (Otto Wilhelm Hermann von Abich, Ludwig Friedrich Kämtz, Adolph-Theodor Kupffer, Karl-Julius Fritzsche etc.) were his protégés and long-time correspondents, thankfully sharing the results of their researchers with the patron. On 25 February 1833, Humboldt wrote to Uvarov from Berlin: "I together with my learned friend Mr. Mitscherlich]Eilhard[(a famous German chemist) would recommend a young man (Mr. Fritzsche), having been distinguished for a witty use of chemical methods to the plant organization study; for several years he has been our Academic Laboratory Head. I think, it would be an excellent acquisition, and I dare to ask you <...> to give him your protection" (RGIA, coll. 735, aids 1, fol. 413, p. 6).

While "the Emperor deigned to entrust [Uvarov] the Ministry of National Education", he willingly informed his "famous friend", that he had fortunately obtained more official channels to promote the German professors (RGIA, coll. 735, aids 1, fol. 413, p. 7, 16). Congratulating him on the new appointment, Humboldt did not forget to remind "his President" that Kupffer's life and work conditions "might be improved" (RGIA, coll. 735, aids 1, fol. 413, p. 8). For decades he continued to trace his protégés' careers and achievements (OPI GIM, coll. 17, fol. 41/174, pp. 193-197; RGIA, coll. 735, aids 1, fol. 413, p. 11). Many of them got their first "Russian" positions at Universität Dorpat, the Empire's most western one. The language of instruction there was German. So, the newcomers did not experience much language or cultural difficulties. 
Since Humboldt, as he wrote, was "doomed to constantly bother Your Excellency with my "Dorpat" interests" (RGIA, coll. 735, aids 1, fol. 413, pp. 13-14), almost all his letters in the 1840 -s contain suggestions about the proper candidates for the University chairs. On 2 June 1842, he wrote from Sans Souci: "Your Excellency has just made two very successful acquisitions to improve the study of physics and geology at the University of Dorpat. Mr. Kämtz and Mr. Abich are two scientists, whose departure I would regret, if I did not know, that we had no conditions to offer them the position and the wide field of research, that could be provided to them under your patronage" (OPI GIM, coll. 17, fol. 41/174, p. 193).

In 1842 Abich, promoted by his famous teachers - Humboldt and Christian Leopold von Buch, was appointed there as a professor of mineralogy. Henceforth, he spent most of his time constantly travelling around the Empire. Semyon Vengerov asserted, that " $<$ Abich $>$ created the geology of that region, having been almost undeveloped before him <...>" (Vengerov, 1889). For many years Humboldt went on asking Uvarov about his expeditions. On 13 July 1842, he reminded Uvarov: "As well as my friend, the great geologist Leopold von Buch, I am interested in Mr. Abich's achievements <... . He is one of the most outstanding people in Germany, studying nature with all the insight of an excellent observer $<\ldots>$. He will give you $\langle\ldots\rangle$, what is currently least studied - the application of chemistry to geology $\langle\ldots\rangle$. If he succeeded under your aegis $\langle\ldots\rangle$, he will someday visit Ararat and the volcanic region between Erivan, Lake Van and Tabriz!" (RGIA, coll. 735, aids 1, fol. 413, p. 11).

\section{PROFESSIONAL CREDO}

Three years later, he again thanked Uvarov for his "very special patronage <...> to Abich, travelling around Ararat" (OPI GIM, coll. 17, fol. 41/174, p. 195-196). Speaking about his innovative researches, Humboldt described his own ideal of the Scientist: a hardy explorer, a mature naturalist and a gifted artist: "Mr. Abich has a rare advantage: he is a geologist, a talented chemist and a draftsman!" (OPI GIM, coll. 17, fol. 41/174, p. 195-196). On 5 November 1847, he once more praised his friend's virtues and proclaimed their joint professional credo, - the extensive field research had to be followed by immediate processing of its results: "Mr. Abich, whom we consider to be the first German geologist after Mr. Leopold Buch, will bring the most valuable results of his observations, and it is necessary, that he would not allow them to become obsolete. Science goes ahead in quick steps; an expedition should never drag on for too long. It is not good, if the observation results are published, when the scientific horizon has already expanded in many directions" (OPI GIM, coll. 17, fol. 41/174, p. 197).

Being aware of Uvarov's interest to antiquity, Humboldt gave references to several philologists, Philipp August Böckh's students. They did not become as famous in Russia as their colleagues - geographers, physicists or chemists. We know only their family names Dr. Gantl, Dr. Merker. In May 1843, he characterized in a playful tone a new university professor: "Dr. Merker, one of Böckh's most prominent students in the field of Hellenism, was elected to the Department of Philology in Dorpat. I would highly recommend him to the high patronage of Your Excellency. <.. > You said in your etudes: "Metaphysics, which assumes facts, can never satisfy the human mind". This axiom makes me hope, that in Dr. Merker you are happy to find a mix of philology, history and philosophy, a mix that excludes empty and fantastic assumptions. Mr. Merker is a solid scholar and speaks various modern languages even Polish. You will see from the attached work, that the only sin, I know of him, is that he writes Greek verses" (RGIA, coll. 735, aids 1, fol. 413, p. 13-14).

It is remarkable that Humboldt always introduced "scientists" himself, while advising "scholars" mainly referred to experts' opinion. On 29 June 1841, he wrote from Paris: "I dare ask my president for high patronage in favor of a German philologist Dr. Gantl, who travels to St. Petersburg after long studies in libraries and manuscript repositories in Rome, Florence, Oxford, Paris and Germany. <...> He published works on Persia and on Horace, based on the sources, which no one has yet scooped. "Snack" from Greek manuscripts also attracted 
him. Böckh, Gottfried Hermann and Amman from Dresden speak about Mr. Gantal's moral qualities in the most favourable way. I feel, that my recommendations will be for Your Excellency something of an intermittent illness" (RGIA, coll. 735, aids 1, fol. 413, p. 10).

In the same letter he personally evaluated another Dorpat professor - anatomist Karl Bogislaus Reichert, speaking as a specialist about his "ovology" researches. Repeating his appeals, Humboldt even complained to Uvarov about incessant "brain drain" from Germany to Russia: "Maybe you will ask, why I deprive my country of people, about whom I speak with a great praise. I answer again, that we are educating more scientists, than we can feed; that your universities offer better positions than ours; I answer, that I believe in the scientific republic, where different nations of Christian and civilized Europe should begin mutual exchange <.. .>" (RGIA, coll. 735, aids 1, fol. 413, p. 13-14).

Promoting his colleagues, Humboldt always described only their professional skills, profound knowledge, and novelty of their ideas. On 8 September 1839, he reminded Uvarov about an outstanding embryologist Robert Remak: "We have here one young scientist <...> who, having received the second prize at the Medical Faculty of Berlin University, became famous for his analytical studies, very subtle, very curious, related to the structure of the nerves $\langle\ldots\rangle$. It seems to me, that there is a currently free vacancy in physiology at Vilnius Medical Academy. < . .> The young man belongs to the Jewish religion. And his scrupulosity, which you do not blame, would prevent him from converting to Christianity only for profit reasons. He hurried to write to Vilna, that he was a Jew, and that the Academy should be aware of this circumstance. I know, your legislation, very tolerant in the affairs of national beliefs, makes it easy to eliminate the difficulty in some cases viewing one's personal merits $<\ldots>$. I would like to hope, that Your Excellency will also regard this case as an exception" (OR RNB, Vaksel's coll., fol. 1310, p. 1).

\section{6 "KEY TO CENTRAL ASIA"}

Among other significant topics, discussed by the correspondents in the 1830-1840-s: newly published works, organization of international scientific periodicals, book exchanges between Russian, Prussian and French institutions, information about Europeans' voyages to the country. Their expeditions throughout the Empire, especially to its eastern regions, surely faced a lot of difficulties not only climatic or transport ones. Red tape poisoned the society, so Humboldt asked "his President" "to appease and mitigate the griffins guarding these treasures" (RGIA, coll. 735, aids 1, fol. 413, p. 9).

Almost in every letter they informed each other about their recent achievements. On 18 May 1843, being in Potsdam Humboldt notified his interlocutor: "I had the high honor to acquire an excellent compilation of your works, devoted to philology, and poetry, and the beginnings of philosophy (Ouvaroff, 1843). I reread your Mysteries with the infinite pleasure (Uvarov, 1812). <..> I once again admired the elevation of the style which as always stems from the sublime order of the soul" (RGIA, coll. 735, aids 1, fol. 413, pp. 13-14).

He also reported, that he finally received the monograph devoted to his rather short but fertile expedition in 1829: "I decide to ask Your Excellency to accept with the favorable indulgence, that you have been giving me for so many years, a respectful offering $<\ldots$. , only a few days ago I received a copy of my "Central Asia". Some introduction pages $<\ldots>$ should attract my President's attention. Perhaps, a sense of scientific modesty should have forced me to refrain from the thought of presenting you a book, teeming with numerical calculations, the enemies of any thought" (RGIA, coll. 735, aids 1, fol. 413, pp. 13-14).

Humboldt regarded himself as an ambassador of the "scientific republic" and regularly tried to organize long-lasing collaborations between the institutions of different countries. On 22 October 1838, working at the "Institute Palace" in Paris, he advised to arrange continuous relations with Stanislas Aignan Julien, an eminent French sinologist: "Concluding the letter I dare appeal to my President with a humble request for a very respectable person, Mr. Julien, a member of the Institute, with the greatest zeal engaged in historical and geographical research in Central Asia. My friend, Mr. Julien, has already donated 116 Chinese books to St. Petersburg Imperial 
Academy for the exchange $<\ldots$. . Mr. Julien added to them all his published works. He extremely needs the geographical dictionary $\mathrm{Si}$-iu-thonbg-wen-tchi, which is available $<\ldots .>$ in the Imperial Library, as well as Li-tsi or the book of rituals. $<\ldots>$ The special propensity, that I have for Central Asia, makes me convincingly ask you $\langle\ldots\rangle$ not to refuse to facilitate these negotiations. I take it very close to my heart. With his package Mr. Julien has beforehand proved the extent, to which he wanted to be useful to your Academy, and it might honor him very well by electing him as its member. He had deserved it with his deep knowledge, the softness of his character and the services, that he likes providing to all Russian travelers" (OR RNB. Foreign Autographs coll., fol. 603, pp. 1-4).

We do not know, what should be blamed, - the Russian beadledom or the pace of international communications at that time, but four years later Si-iu-thonbg-wen-tchi had not been sent to Paris. On 28 September 1842, Humbuldt had to hurry up Uvarov's subjects: "The publication of this work would be extremely important for the history and geography of highland Asia. <...> My love of geography makes me be intrusive. When you live to 73 years old, you need to hurry to enjoy life" (OPI GIM, coll. 17, fol. 41/174, p. 194).

Wishing to popularize knowledge about Siberia and Central Asia, Humboldt advised to open the so called "Asian Journal". On 20 July 1838, he once again reminded: "The key to Central Asia is in your hands. An Asian journal, that would be published under your supervision, could increase the knowledge about this part of the world" (RGIA, coll. 735, aids 1, fol. 413 , p. 8). He repeated the same idea a decade later: "It would be very desirable for Mr. Kämtz to publish a physics journal in Dorpat, that would put Europe in a closer contact with your vast Empire stretching from the permafrost zone to the Herodotus plains and the sugar cane zone" (OPI GIM, coll. 17, fol. 41/174, p. 193).

\section{CONCLUSION}

Their friendly communication did not stop after Uvarov's resignation in 1849. On 21 February 1851, Humboldt solaced his vis-à-vis recalling his achievements as a minister: "Count, if I were late to bring to Your Excellency the expressions of my admiration and my respectful devotion, < . . > I cannot forget the noble services having been rendered by you as a statesman to the sciences which I am mostly engaged in and to the classical literature from which you yourself draw your happy inspiration. Pulkovo <observatory > is a monument of Astronomy erected by you under the auspices of the great monarch; it surpasses all that has been built so far. $<\ldots>$ How I should regret that in order to recuperate $<\ldots>$ you turned to the peace and quiet of scientific life, the joys of which you know" (OPI GIM, coll. 17, fol. 41/174, p. 198).

Letters, sent in the 1850 -s, no longer contain petitions to promote anyone or to participate in any international project. Ceasing to be a minister, he returned to scholarly studies in his manor house in Porechie. Revolutionary events, stunning the European aristocracy, became the constant subject of two elderly gentlemen's fears. Reminding Humboldt about his 1829 expedition and their meetings, Uvarov also emphasized their ideological kinship. In his last letter sent in August 1852 he wrote about their mutual rejection of the revolutionary extremes: "The time of your stay in St. Petersburg will remain one of the most pleasant memories of both public and private lives of mine. <...> As you know, I maintained the same love to the true progress of the human mind. I think, as either you or all genuine conservatives in Europe would have not understood our most cherished interests, if we had elevated to the principle of those extremes and criminal abuses we had witnessed and have been still witnessing. Let us hope, that a true civilization, a progressive civilization will soon cease to be a victim of terrible abuses $<\ldots$. . But I stop talking, because you can add a lot more on this topic while I have neither time nor place. I, therefore, limit myself in assuring you again, dear and respected colleague, in my deep and long-standing respect" (OPI GIM, coll. 17, fol. 41/126, pp. 227-228).

As we have mentioned in the introductory lines of our preliminary survey, our initial research task was rather restricted. We just tried to give a general overview of the main topics raised in Humboldt's letters to Uvarov. It is clear, investigation of their correspondence should be continued. Here we have just retold some interesting and important pieces of 
Humboldt's letters. Such translation significantly reduces the value of the quoted fragments. They have to be published in the original language, with proper translation, and comments. Uvarov's letters to Humboldt also ought to be located.

\section{REFERENCES}

Knobloch, E. (ed.) 2009. Alexander von Humboldt. Briefe aus Russland 1829. Berlin. Briefe 87.

Ouvaroff, S. 1843. Etudes de Philologie et de critique. St. Petersburg.

Shcherbakov, D. (ed.) 1962. Alexander Humboldt's correspondence with scientists and statesmen of Russia, Moscow.

Suhova, N. 2006. Alexander von Humboldt in Russian literature: the annotated bibliography. St. Petersburg.

Svin'in, P. 1829. About Baron Humboldt, Otechestvennye zapiski, 38, pp. 280-283.

Séance extraordinair, tenue par l'Academie Impériale de Sciences de St.-Pétersburg, en l'honneur de M-r le baron Alexandre de Humboldt du 16 November 1829. St. Petersburg, 1829.

Uvarov, S. 1812. Essai sur les Mystères d́ Eleusis. St. Petersburg.

Vengerov, S. 1889. 'Abykh German Vilgelmovich', Critical-biographical dictionary of Russian writers and scientists, vol. 1, pp. 8-11. 